This is an electronic reprint of the original article. This reprint may differ from the original in pagination and typographic detail.

Author(s): Vähäsantanen, Katja; Paloniemi, Susanna; Hökkä, Päivi; Eteläpelto, Anneli

Title: $\quad$ Agentic perspective on fostering work-related learning

Year: $\quad 2017$

Version:

Please cite the original version:

Vähäsantanen, K., Paloniemi, S., Hökkä, P., \& Eteläpelto, A. (2017). Agentic perspective on fostering work-related learning. Studies in Continuing Education, 39(3), 251-267. https://doi.org/10.1080/0158037X.2017.1310097

All material supplied via JYX is protected by copyright and other intellectual property rights, and duplication or sale of all or part of any of the repository collections is not permitted, except that material may be duplicated by you for your research use or educational purposes in electronic or print form. You must obtain permission for any other use. Electronic or print copies may not be offered, whether for sale or otherwise to anyone who is not an authorised user. 


\title{
Agentic perspective on fostering work-related learning
}

\author{
Katja Vähäsantanen, Susanna Paloniemi, Päivi Hökkä \& Anneli Eteläpelto
}

Department of Education, University of Jyväskylä, Finland

\begin{abstract}
Despite the increased recognition of the role that professional agency plays in work-related learning, little is known about what supports it. Based on current theoretical notions, the first purpose of this paper is to show that professional agency is closely intertwined with work-related learning. The second purpose is to introduce some main principles that promote professional agency and describe three work-related training settings that are aimed at fostering learning by taking into account agentic perspectives. These complementary settings include an identity coaching programme, a leadership coaching programme, and a work conference. Based on the qualitative meta-synthesis, the paper further provides an empirical overview of professional agency and learning in these settings. The paper contributes to the understanding of the potential of professional agency at the heart of work-related learning. To foster learning, it is necessary to create social events for the enactment and activation of agency so that social and individual resources (e.g. experiences) are utilised. Overall, the paper emphasises that individuals and communities are active crafters of their professional identities and practices, and it provides viewpoints to support their agency in work and training settings.
\end{abstract}

Keywords: professional agency; professional identity; training settings; workrelated learning

\section{Introduction}

Amid the economic, managerial, and societal challenges of the 21 st century, work organisations are increasingly expected to develop their work practices, operations, culture, and structure to produce high-quality innovative services, be productive, and respond to accountability demands (Alasoini 2011; Billett 2010; Kira 2010; Tynjälä 2013). Simultaneously, employees are expected to develop their professional 
competencies, work practices, and professional identities (Billett 2011; Eteläpelto et al. 2014; Harteis and Goller 2014; Kira and Balkin 2014; Reich, Rooney, and Bound 2015). Similarly, leaders need to undertake new tasks and cultivate their identities (Carroll and Levy 2010; Lovett, Dempster, and Flückiger 2015), because the focus of their work is moving towards adopting novel leadership practices. This shift includes leading people and their collaborations and supporting their active participation, identity work, and innovative learning at work (Hökkä and Vähäsantanen 2014; Townsend and MacBeath 2011). Despite the pressing need to support comprehensive learning at the individual, collective, and organisational levels, so far, these kinds of training settings and intervention strategies have been lacking in work organisations. Generally speaking, the training methods and interventions that have been implemented have been aimed at supporting either the development of professional identities and competencies (e.g. Leitch 2010) or the transformation of work practices (e.g. Haapasaari and Kerosuo 2015).

In parallel with the need for comprehensive learning at work, notions of professional agency have emerged in the area of learning, including the development of professionals, work communities, and organisations (Billett 2011; Eteläpelto et al. 2014; Harteis and Goller 2014; Imants, Wubbels, and Vermunt 2013; Philpott and Oates 2016; Pyhältö, Pietarinen, and Soini 2015; Smith 2012; Tynjälä 2013). While seeing the development of professional knowledge and skills as an important part of work-related learning, this paper addresses learning mostly as the formation and transformation of professional identities and work practices. Further, professional agency is understood as an action-based phenomenon rather than as individuals' capacity or property.

The notion of professional agency includes the idea that employees are responsible and active actors in work contexts. Without opportunities for professionals 
to exercise agency (manifested as active participation, making decisions and suggestions, and influencing) at work, the emergence of productive work practices, innovative solutions, and meaningful professional development might be threatened (Harteis and Goller 2014; Lovett et al. 2015; Vähäsantanen 2015). Thus, professional agency and supportive social affordances for its enactment are essential to the processes of work-related learning and organisational development.

The next section of this paper elaborates on how professional agency is understood as being intertwined with work-related learning. The main argument covers the idea of professional agency as a prerequisite for work-related learning, although agency can also be conceptualised as a learning outcome (Tynjälä 2013). Despite the emerging recognition of the role which agency plays in learning, little is known about how agency can be supported in working life. According to Engeström (2011), the basic shortcoming of work-related training is often ignorance of participants' agency and how it is supported. Therefore, there is a need for well-articulated perspectives and training settings on supporting professional agency in and for work-related learning. This paper contributes to filling this gap by describing the practical principles of promoting agency and by introducing three work-related training settings - an identity coaching programme, a leadership coaching programme, and a work conference - aimed at fostering work-related learning according to these principles.

Based on a qualitative meta-synthesis (e.g. Sandelowski and Barroso 2006) of five empirical studies, we also present the main findings concerning agency and learning in these interventions. These particular training initiatives were part of a project aimed at supporting professional agency in Finnish education and health care contexts. Although one could say that the learning in these settings occurs outside of everyday practices, learning is highly practice-based; it is closely related to professionals' 
everyday work practices, professional identities, and knowledge (Reich et al. 2015). Finally, the paper provides an overview of its theoretical contribution and creates openings for creating agency-promoting learning environments.

\section{Conceptualisation of professional agency intertwined with work-related learning}

Although professional agency is conceptualised in various ways in educational and working life studies, it is mostly related to various kinds of choices and intentional actions, participation in social relationships, and the influence on work-related matters (Eteläpelto et al. 2014; Priestley, Biesta, and Robinson 2015). Some scholars understand agency merely as the capacity, ability, property, or disposition directing individuals' choices (e.g. Emirbayer and Mische 1998; Harteis and Goller 2014). Others tend to conceptualise agency more as an action-based phenomenon; it refers notably to influencing, making decisions and choices, and taking stances, in a way that makes a significant difference (Eteläpelto et al. 2013; Haapasaari and Kerosuo 2015). We also adopt the understanding of professional agency as an action-based phenomenon. Next, we introduce how the connection between professional agency and work-related learning is conceptualised in the literature. Learning is notably seen as the formation and transformation of professional identities and work practices.

Thus far, professional agency has been addressed mostly in relation to work and work practices. According to Lukic, Margaryan, and Littlejohn (2013), agency at work refers to making decisions and judgements related to one's work and it further supports organisational development. In its most proactive forms, professional agency can be seen as enacted by undertaking creative initiatives and making suggestions for developing existing work practices and transforming a given frame of action (Engeström 2011; Haapasaari and Kerosuo 2015; Paloniemi and Collin 2012; 
Virkkunen 2006). This kind of change-oriented agency can be conceptualised as transformative agency. Transformative agency is also practiced via innovating individual and collective ways of working, addressing tensions in work practices, and questioning the existing activities and practices at work (Harteis and Goller 2014; Vähäsantanen 2015). However, professional agency can also manifest in ways that are less proactive and developmental, such as by reproducing professional practices and resisting calls for change (see Priestley et al. 2015; Toom, Pyhältö, and Rust 2015). Further, evidence has been found that strong individual agency that maintains the existing work culture and practices may actually work against organisational change (Hökkä and Eteläpelto 2014).

Indeed, the manifestations of agency are not always development-oriented or individual by nature. Collective agency is needed to build a shared understanding and subsequently create new work practices, and to introduce innovation at work (Paloniemi and Collin 2012). However, individual and collective forms of agency are not separate. For example, transformative agency often starts with individual initiatives and then expands to collective endeavours and outcomes over time. Even though the first expression of transformative agency is initiated by an individual, it requires collaboration and shared activities to survive and expand (Haapasaari and Kerosuo 2015). The latter findings have emerged especially in the framework of culturalhistorical activity theory. This approach conceptualises agency relative to learning, understood as the transformation of activity at work (see also Engeström 2011), but ignores how professional agency and identity are related.

On the contrary, Billett $(2010,2011)$ emphasises that work-related learning includes the transformation of work practices and the negotiation of professional identity, and that professional agency plays a pivotal role in both processes. In 
theoretical terms, the professional identity of an employee or a leader is understood as the individual's history-based perception of him/herself as a professional. In this sense, professional identity is closely related to employees' life and work histories, but it also includes professional goals and interests, commitments, ethical standards, and future prospects at work (Beijaard, Meijer, and Verloop 2004; Carroll and Levy 2010; Eteläpelto et al. 2014; Kirpal, Brown, and Dif 2007). Accordingly, professional identity is closely linked to a-past-present-future continuum (see also McAlpine and Amundsen 2015).

Further, professional identity can be recognised as a collective phenomenon. Collective or group identity refers to shared professional commitments, beliefs, and missions, and to the mutual identification, togetherness, and engagement that binds individuals as a professional group (Admiraal, Lockhorst, and van der Pol 2012; Davey 2013). Professional identity has consequences for employees' work behaviour, collaboration, and development, and therefore contributes to the quality of the organisation's services (Admiraal et al. 2012; Beijaard et al. 2004; Kira and Balkin 2014; Molleman and Rink 2015).

In the case of professional identity, professional agency can be enacted through activities, the aims of which range from the maintenance of to the transformation of professional interests and commitments (Kira and Balkin 2014; Vähäsantanen 2015). According to Ruohotie-Lyhty and Moate (2016), this kind of identity-agency can include forms of taking a new direction for the future, losing confidence, and monitoring the environment. Identity-agency can also be enacted in terms of planning and directing an individual's professional pathway and deliberately pursuing learning activities (Harteis and Goller 2014; Kirpal et al. 2007) and undertaking means of advancing individuals' intentions and hopes in their work practices (McAlpine and 
Amundsen 2015). Agency in its transformative form is especially needed in situations where an individual's professional identity is in conflict with his/her work. To resolve such a conflict without negative outcomes (e.g. decreasing well-being and commitment at work), each employee must renegotiate his/her identity to ensure that it corresponds with the existing work practices or must renew his/her work practices (Kira and Balkin 2014; Vähäsantanen 2015).

Overall, on the basis of theoretical notions presented, this paper argues that professional agency is notably enacted via influencing and making suggestions, choices, and decisions in ways that affect work practices and professional identities. Furthermore, these agentic actions, carried out individually and collectively by professionals, can foster learning (including the transformation of professional practices and professional identities). Consequently, professional agency is understood as a necessary condition for work-related learning (see also Harteis and Goller 2014). Next, the paper introduces the main principles for promoting professional agency.

\section{Principles for promoting professional agency}

In understanding which features influence agentic decisions and actions, some researchers have focused on identifying personal backgrounds that seem conducive to agency (e.g. van der Hejden et al. 2015), whereas others have focused more on contextual and social factors. For example, the meaning of professional communities and relationships has been addressed in relation to the development and exercise of agency in working life (Philpott and Oates 2016; Riveros, Newton, and Burgess 2012).

The subject-centred sociocultural approach (Eteläpelto et al. 2013, 2014) adopted in this paper emphasises that professional agency is both resourced and constrained by communities and sociocultural conditions (including power relations and discourses, material conditions, and social interaction cultures) and individual 
backgrounds (including professionals' work experience and knowledge). Similarly, other authors (Priestley et al. 2015; Toom et al. 2015) have suggested that both personal and social factors shape, facilitate, or restrict professional agency. More specifically, this means, for example, that employees do not make suggestions for developing work practices without having sufficient professional competencies and familiar relationships with other people (Vähäsantanen 2015). Lukic et al.’s (2013) study on individual agency in learning also reveals that both individual (values, experience, and confidence) and organisational factors contribute to fostering individual agency. All this highlights the role of individual backgrounds (professional knowledge, intentions, and history) in professional agency, along with the sociocultural practices.

To be more precise, regarding the development of shared work practices and organisations especially, traditional power relations and professional positions can act as obstacles to agency and shared learning (e.g. Paloniemi and Collin 2012). Therefore, the enactment of agency for changing the course of activities requires the renegotiation of traditional hierarchical, professional, and organisational boundaries (Virkkunen 2006). Thus, for supporting the enactment of professional agency, it is critical to create equal and dialogical learning settings. Among others, Alasoini (2011) emphasises the importance of creating mutual dialogue with opportunities for employees' active participation (including listening, expressing experiences, and making suggestions) for generating workplace innovations. Haapasaari and Kerosuo (2015) also point out that creating and sustaining innovations and transformations in work organisations demands that each employee has opportunities to communicate and express his/her needs and concerns and suggest potential solutions to problems.

To promote professional agency as part of the professional identity negotiation, it is also important to create shared dialogical arenas. In these arenas, professionals 
(employees and leaders) need to be able to make sense of themselves in the continuum of past, present, and future, share their experiences, and understand and re-create their relationships with the changing work practices, their work community, and their organisation (Carroll and Levy 2010; Leitch 2010). In the case of supporting the emergence of identity-agency, an array of practical experiences and individuals' own personal histories are also extremely meaningful. Identity-agency is further enabled by membership in a specific group and having one's participation recognised by other members of the group (Ruohotie-Lyhty and Moate 2016). Indeed, it is essential to create social arenas for negotiating and shaping one's professional identity, as identity is always constructed through professional relationships (Admiraal et al. 2012; Davey 2013), although agentic efforts also mediate the negotiation of professional identities (Geijsel and Meijers 2005). In this sense, social communities and other people are seen as resources for identity negotiations.

Overall, to support professional agency relative to professional identity and work, it is necessary to create learning and training settings where agency-promoting principles are acknowledged. Social learning and training settings are needed for resourcing employees individually and collectively to enact professional agency in terms of influencing, taking stances, and making decisions and suggestions. To make this possible, the obstacles to professional agency need to be recognised and diminished, and individuals must be able to utilise their individual and collective resources (e.g. work experience and history). To sum up, the social events (with supportive frames for reflecting and working on work-related issues) that support and enable enacting professional agency can result in work-related learning aimed at the development of professional identities and practices. Next, this paper introduces three work-related training settings in which theoretical grounding (embedded particularly in 
the subject-centred sociocultural approach) and practical principles concerning agency are acknowledged.

\section{Work-related training settings}

As part of a project in Finnish education and health care contexts, work-related training settings were created to foster work-related learning by supporting the enactment of professional agency in relation to professional identity and work practices. The complementary training settings included (i) an identity coaching programme aimed at supporting employees' professional development, particularly their professional identity negotiations, (ii) a leadership coaching programme aimed at supporting the cultivation of leaders' identities and work practices, and (iii) a work conference aimed at promoting the development of shared work practices.

The training settings in question were selected for the project because they were evaluated as settings with the potential to support the professional agency of the participants. Further, together, these settings were seen to enhance comprehensive work-related learning in work organisations. Each training setting had specific aims and agentic principles that were understood to support the achievement of their aims. Besides, the authentic learning processes were also framed by the needs and concerns of professionals and organisations. Therefore, the actual learning could be unique. Overall, the settings were aimed at supporting the participants with work-related matters, such as professional practices and identities. This contradicts the frameworks - which are generally questioned (e.g. Reich et al. 2015) - aimed at capturing pervasive competencies in working life and using these to drive education and training. The following sections describe these three training settings, along with their practices for promoting professional agency. 


\section{Identity coaching programme}

The main purpose of the identity coaching programme is to support participants' professional identity negotiations by increasing their awareness of themselves and their relationship to their work environment (Mahlakaarto 2014). Overall, the programme is aimed at helping the participants strengthen and reshape their professional identity, clarify their work roles amid changes, strengthen their professional role in their work communities, and increase their wellbeing at work.

The identity coaching programme includes four thematic components: personal identity, professional identity, relationship identity, and organisational identity (Mahlakaarto 2014). The purpose of personal identity is to become aware of one's own unique life story, special qualities, and personal strengths. Regarding professional identity, the focus is on one's own professional history, professional expertise, values, future prospects, and developmental needs at work. Concerning relationship identity, attention is given to social roles and relations within work communities. Finally, organisational identity focuses on the participants' relationships to their organisation and its structures and practices. The objective of the programme is to create a socially supportive arena for reflecting on, and working with, these four components. The overall aim is for the participants to become aware and empowered to make decisions about their identity, roles, and wellbeing at work (Mahlakaarto 2014). That is, it is through the creation of this kind of setting that the programme promotes professional agency.

The identity coaching programme is implemented as a group training initiative led by an experienced coach, and it consists of six workshops conducted over a sixmonth period (totalling 18 hours). The core of the programme is social interaction, as the focus of the training is on reflecting and sharing one's own experiences, ideas, 
perceptions, and emotions with other group members. To promote this interaction, the group training is based on various collaborative, action- and arts-based, and narrative methods. These include the application of sociometry, sociodrama, discussions in pairs and groups, and drawing and writing activities. The aim of these methods is to foster professional development at both the cognitive and emotional levels and to enhance the awareness of embodied and tacit (non-articulated) knowledge as opposed to merely discursive knowing (e.g. Taylor and Ladkin 2009).

During the first workshop, the participants discuss and agree upon the basic task for the group and the ethical and functional commitments expected regarding shared work. The aim is to create a safe and trustful learning environment. The programme also includes training materials and individual tasks between the workshops to promote a deeper exploration of one's own professional development in relation to the thematic components of the programme. One method involved in the programme is the Professional Body that aims to support participants' professional identity negotiations (see Vähäsantanen et al. 2016). As a homework assignment, the participants reflect their professional identities from the viewpoints of the past (e.g. meaningful experiences), present (e.g. professional goals), and future (e.g. professional dreams, future directions). Each participant demonstrates these themes through various means (e.g. writing, painting, using clippings) on a paper where the outline of one's own body is drawn. The individually constructed bodies serve as material for collective sharing and working in a workshop meeting. This, and other methods, are used to enable both collective meaning construction and personal sense-making among the participants (see also Geijsel and Meijers 2005).

\section{Leadership coaching programme}

The general purpose of the leadership coaching programme is to support leadership 
development by creating a space for dealing with one's own identity as a leader and for developing various practices and skills for leading and developing the personnel. In particular, the programme is aimed at supporting the cultivation of leaders' identities, to build agency-promoting leadership that involves enhancing the collaboration and influence between actors throughout the organisation, and to offer means for supporting the personnel's professional identity work.

The aims imply that the programme combines individual and social components of leadership, making it possible to focus on leadership in social and organisational contexts and on leaders as individuals with professional skills and identities. Recent discussions have emphasised this kind of interplay between the individual leader and the environment in leadership learning (Day and Harrison 2007). Overall, the programme is aimed at supporting leaders in considering and making a difference concerning their professional identities and leadership practices.

The leadership coaching programme includes 12 workshops run over the course of a year (6 hours per workshop). An experienced coach is responsible for the implementation of the programme. Similar to the agentic principles and practices of the identity coaching programme, the leadership coaching programme is implemented via collaborative small group training, utilising different arts and action-based methods (e.g. pair and group discussions, sociometry, drama activities, and drawing). The aim is to create a setting for shared learning, further enriched by theoretical and practical ideas offered by the educator. During the programme, the participants also construct individual portfolios and conduct developmental projects which emerge from the needs of their work and work communities. From the viewpoint of supporting professional agency at work, these projects are aimed at increasing the personnel's professional 
agency in relation to their identities and work practices, work communities, and organisational practices.

\section{Work conference}

The work conference is aimed at creating space for developing collective work practices in work organisations. In our research project, both work conferences in the university focused on developing a future vision for a participating unit. In the hospital, the theme was developing patient-centeredness and common rules for shared work.

The conference is implemented through small group and joint group democratic discussions promoting professional agency. In this sense, the work conference offers participants a shared and equal learning space in which they can collectively reflect on, and utilise, their past experiences and, based on this, create the future vision for their shared work (Kalliola and Nakari 2006). The importance of equality is highlighted to overcome the constraints surrounding unequal power relations in the enactment of professional agency.

A work conference can be conceptualised as a dialogue-oriented approach when implementing organisational and communal changes, as the participants are prepared to genuinely listen to each other and critically analyse their viewpoints and work practices (Kalliola and Nakari 2006). At best, this kind of interaction can generate solutions and innovations that would have been impossible to create through the independent effort of any individual participant (Alasoini 2011). In enabling the collective sharing of ideas and experiences, the work conference becomes a method for learning from others (Kalliola and Nakari 2006), which can stimulate both individual and collective agentic actions, and thus promote the development of shared work practices.

In order to promote agentic actions and discussions among the participants, the method includes specific ground rules that are introduced as guidelines for the dialogue 
(Gustavsen and Engelstad 1986). One of the central rules is to value the work experience of each member. Furthermore, it is emphasised that dialogue is based on the principle of give and take and not on one-way communication, and all participants have the same status in the dialogue. The rules give all participants an active voice that allows them to be recognised in the dialogue.

First, in the planning phase of a work conference, a steering group representing all stakeholders and hierarchical levels in question (i.e. employees and leaders, all professional groups) is established. The steering group has two tasks: first, to determine the theme of the work conference and, second, to work on, and take responsibility for, realising the action plans produced as outcomes. The basic model of the actual work conference involves the interplay of small group sessions and plenaries. There are four phases of small group sessions: (i) working on the vision for the theme in homogeneous groups (e.g. professional groups), (ii) working through the obstacles or problems that are in the way of realising the vision in diagonal groups (e.g. multi-professional groups), (iii) working on the means of solving the problems in voluntary groups, and (iv) creating concrete action plans in natural groups (i.e. employees who work in the same unit). After each phase, the group outputs are presented in plenaries.

\section{Methods}

Altogether, six identity coaching programmes (59 participants) and three work conferences (92 participants) were initiated. At a university, three identity coaching programmes (one for administrative personnel and two for teachers and researchers) and two work conferences (one for administrative personnel and their managers and another for teachers, researchers, administrative personnel, and their managers) were implemented. At a hospital, three identity coaching programmes (one for physicians and two for nurses) and one work conference (for nurses, doctors, administrative personnel, 
and their managers) were carried out. Furthermore, a leadership coaching programme was implemented for 11 middle managers from both contexts.

All the identity and leadership coaching programmes were video-recorded. The participants were individually interviewed before (e.g. the perceptions of their identity, agency, and developmental needs at work) and after (e.g. the perceived learning outcomes and processes) the programmes. Similarly, the work conferences were videorecorded and their small group discussions were audio-recorded. The participants further completed assessments (e.g. benefits of the work conference and assessment of the working methods) both immediately and shortly after (about three weeks) the work conferences.

The aim of this paper is to provide an overview of professional agency and learning through the settings described above. In doing this, we apply a meta-synthesis approach to provide a comprehensive picture of the findings, drawing on primary studies on the research topic (Sandelowski and Barroso 2006; Timulak 2009). Five primary studies concerning the three training settings were utilised in the analysis. The focus, participants, and methods of each study are described in detail in Table 1.

The primary studies focused notably on professional agency and learning, but also revealed how these two aspects were supported during the training settings (see Table 1). During the analysis process, we identified the findings from primary studies in order to capture the information on the different forms of professional agency and workrelated learning, as well as the social conditions enabling their emergence. By categorising the main findings of the primary studies within and across the training settings, we were able to conduct a final synthesis on the topic under investigation. 
Table 1. Primary studies utilised in the meta-synthesis.

\begin{tabular}{|c|c|c|}
\hline Focus of the study & Participants & Methods \\
\hline $\begin{array}{l}\text { Agency and learning in an } \\
\text { identity coaching programme } \\
\text { (Vähäsantanen et al. 2016) }\end{array}$ & $\begin{array}{l}49 \text { employees working in } \\
\text { hospital and university } \\
\text { context }\end{array}$ & $\begin{array}{l}\text { Interviews after the programme } \\
\text { Qualitative and quantitative content } \\
\text { analysis }\end{array}$ \\
\hline $\begin{array}{l}\text { The awakening of collective } \\
\text { agency and identity in an } \\
\text { identity coaching programme } \\
\text { (Hökkä, Vähäsantanen, and } \\
\text { Mahlakaarto 2017) }\end{array}$ & $\begin{array}{l}10 \text { employees working in } \\
\text { the university context }\end{array}$ & $\begin{array}{l}\text { Interviews before and after the } \\
\text { programme and its video-recordings } \\
\text { Conventional content analysis and } \\
\text { critical incident method }\end{array}$ \\
\hline $\begin{array}{l}\text { Emotions and learning during } \\
\text { the leadership coaching } \\
\text { programme (Hökkä et al. } \\
\text { forthcoming) }\end{array}$ & $\begin{array}{l}11 \text { middle managers from } \\
\text { the hospital and } \\
\text { university }\end{array}$ & $\begin{array}{l}\text { Interviews before and after the } \\
\text { programme } \\
\text { Qualitative content analysis }\end{array}$ \\
\hline $\begin{array}{l}\text { Learning conditions and } \\
\text { outcomes during the work } \\
\text { conference (Vähäsantanen at } \\
\text { al. forthcoming) }\end{array}$ & $\begin{array}{l}\text { Employees and their } \\
\text { managers from the } \\
\text { hospital and university }\end{array}$ & $\begin{array}{l}\text { Immediate }(\mathrm{N}=71) \text { and follow-up } \\
(\mathrm{N}=41) \text { assessments } \\
\text { Qualitative and quantitative content } \\
\text { analyses }\end{array}$ \\
\hline $\begin{array}{l}\text { Agency and the development } \\
\text { of work practices in the work } \\
\text { conferences (Collin, } \\
\text { Paloniemi, and Vähäsantanen } \\
\text { 2015) }\end{array}$ & $\begin{array}{l}27 \text { staff members } \\
\text { (including managers) } \\
\text { from the hospital }\end{array}$ & $\begin{array}{l}\text { Recordings ( } 11 \text { hours) of the small } \\
\text { group discussions and of } \\
\text { the plenary sessions ( } 2 \text { hours) } \\
\text { Content analysis, ethnographic } \\
\text { analysis of the key incidents }\end{array}$ \\
\hline
\end{tabular}

\section{Findings}

The next sections present the main findings concerning professional agency and learning. In addition, we describe the social conditions that promote agency and further learning in each training setting.

\section{Identity coaching programme: Professional agency and learning}

The empirical study (Vähäsantanen et al. 2016) based on the post-interviews with the participants addressed their learning and agency in the identity coaching programme. The participants perceived the programme as offering a worthwhile learning arena in 
three work-related domains: (i) the professional self (involving a crafted professional identity and work practices), (ii) professional relationships (encompassing awakening collective identity and becoming an active participant in the work community), and (iii) professional competencies (involving socioemotional knowledge and skills). Learning in relation to the professional self, relationships, and competencies was viewed as particularly important for working and collaborating in work contexts.

The findings imply that during the programme, the participants enacted professional agency (in terms of influencing and making decisions) in various ways, since learning occurred in different domains. In particular, transformative agency, which resulted in different kinds of changes in the professionals' lives, emerged. During the programme, the participants especially shaped their professional identities (including professional commitments and career pathways). For example, some university participants crafted their professional commitments more from teaching towards research, and some began new studies based on redefining their future prospects as professionals beyond their current work. Transformative agency also emerged in relation to the participants' practices and relationships at work. This led, for example, to a decision to become a member who actively expresses opinions and makes suggestions in the work community and to set limits for non-work-related interactions with colleagues from the viewpoint of effective working. However, it is important to note that the professional agency of all participants was not enacted during the programme, and thus not all reported learning outcomes in each of the professional domains.

In another empirical investigation into the identity coaching programme (Hökkä, Vähäsantanen, and Mahlakaarto 2017), the group of researchers and teachers was studied from the perspectives of their collective professional identity and agency. This 
investigation was based on interviews with the participants and video-recordings from the workshops. Through the programme, collective identity emerged in terms of increased togetherness, an awakened perception of who the participants were as a group, and a shared, new perception of their important mission and position in the organisation. In relation to this kind of awakened collective identity, the strengthened sense of collective agency also emerged. The participants found a collective will to establish a shared influence in the organisation, with a desire to find workable ways of acting in order to change collective matters and fight for a shared professional mission.

The awakening collective identity and agency appeared to be based on a process whereby the participants were able to share, and work with, their individual narratives. Through sharing their narratives, they were heard and accepted as group members, and they learned about each other. Consequently, trust and affinity within the group increased, and a confidential arena for discussing shared matters, repositioning the group, and for planning shared ways of exerting an influence in the work community was created. Although the programme created the potential for awakening collective agency, the participants did not report any concrete actions towards influencing and developing shared work practices or the work community and organisation.

\section{Leadership coaching programme: Emotions and learning}

Primarily, Hökkä et al. (forthcoming) addressed the emotions of middle managers during the leadership coaching programme, based on the interviews carried out at the start and end of the programme. At the start of the programme, middle managers expressed mostly negative emotions (e.g. inadequacy, distress, and frustration) in relation to the managerial practices and administrative duties. The emotion of inadequacy was frequently conveyed in relation to their professional identity and leadership practices in terms of relationships and interactions with the personnel. For 
example, participants reported feeling inadequate when they perceived that they lacked adequate skills at work and had shortcomings in working according to their professional commitments and ethical principles. At the same time, they felt joy especially in terms of independence and diversity at work and in working with different kinds of people.

One of the most important consequences of the programme was the participants' progress from inadequacy to leniency towards oneself - that is, accepting oneself with one's own strengths and limitations. This progress was based on processing with their professional identity and emotions, and sharing experiences with other middle managers. In this process, the participants learnt to understand and consider their own and others' authentic emotions, respect them, utilise them in decision-making, and act according to them. Conversely, in the area of management practices (implementing strategic decisions, budgeting), the participants still reported unpleasant emotions, particularly exhaustion, without seeing opportunities for influencing these practices or having the power to do so. This was probably at least partly due to the programme's main focus on leaders' identities and work community relations.

\section{Work conference: Professional agency and collective learning}

Our empirical study investigated learning in the context of three work conferences implemented in education and health care organisations (Vähäsantanen et al. (forthcoming). Utilising the participants' assessments, the study revealed the main learning activities and outcomes of the conferences. They notably advanced the participants' dialogical agency (in terms of expressing and presenting one's own ideas and opinions, and as taking stances on the phenomena discussed) and participation across entrenched professional boundaries, especially in small groups. Framed by these activities and conditions, work-related learning occurred at both the individual and collective levels. First of all, learning outcomes encompassed gaining new knowledge 
and becoming a more agentive actor, who expresses his/her opinions and presents his/her stances more actively in professional relationships. Furthermore, collective outcomes included the formation of innovative developmental discussions, changes in shared work practices (e.g. new practices for collaborating and giving feedback), and increased togetherness (i.e. strengthened collective identity).

A comparison between the three work conferences (two at a university and one at a hospital) indicated that the most prominent learning outcomes (in terms of the generation and actualisation of innovative developmental discussions) occurred when the participants were able to enact substantial dialogical agency, when there was comprehensive participation from the work community, and when boundary-crossing occurred. The findings suggest that the most critical points of the unsuccessful development of shared work practices were the limited participation from the whole work community in the conference and the lack of leaders' commitment to implementing the suggestions agreed on at the work conference.

Another study on the work conference focused on professional agency in audiorecorded small group discussions in a hospital context (Collin, Paloniemi, and Vähäsantanen 2015). The study revealed various forms of agency within and across professional groups. On one hand, transformative (e.g. making suggestions for developing multi-professional work practices), responsive (e.g. agreeing with and expanding others' suggestions), and relational (e.g. taking stances from the viewpoint of others) forms of agency emerged in supporting the development of shared work practices. These transformative and proactive (including responsive and relational activities) forms of professional agency were directed at improving the work practices. Together, these forms of agency resulted in producing various visions for developing shared work practices (e.g. nurse-secretary work pairs, forming a system for feedback). 
On the other hand, a resisting form of agency (e.g. opposing and resisting others' suggestions) emerged and seemed to hinder the constructive and innovative development of shared work practices. It appeared that the prevailing power hierarchies were present in the small group sessions and became perceptible through the manifestations of agency, especially in terms of resisting agency.

\section{Discussion and conclusions}

This paper introduced theoretical and practical notions concerning professional agency in work-related learning. It also demonstrated three work-related training settings (an identity coaching programme, a leadership coaching programme, and a work conference) that were orchestrated by utilising agency-promoting principles. Based on the meta-synthesis of five primary empirical studies, the paper further presented insights into professional agency and learning through these training settings.

Figure 1 summarises the main findings of the meta-synthesis concerning three training settings. First, it overviews the forms of professional agency from all three training settings (on the left side of the figure). We argue that these forms create a potential and basis for work-related learning. In addition, Figure 1 demonstrates the kinds of learning (i.e. learning outcomes) that occurred in these settings (in the middle). Finally (on the right side), the figure illustrates the social conditions of the training settings enabling agency and consequently enhancing learning. In presenting a comprehensive overview of the findings, we need to keep in mind that not all the aspects (e.g. forms of professional agency) existed in all of the training settings. Thus, the synthesis illustrates the overall picture of comprehensive work-related training interventions that support professional agency and learning. 


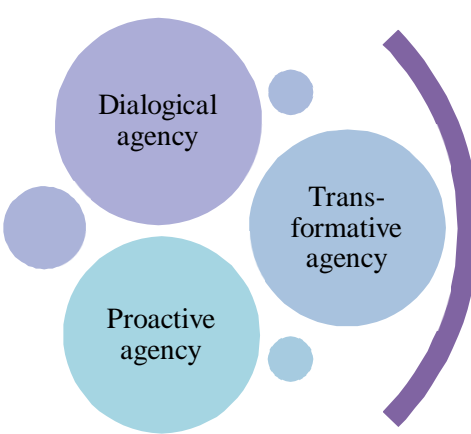

The forms of professional agency

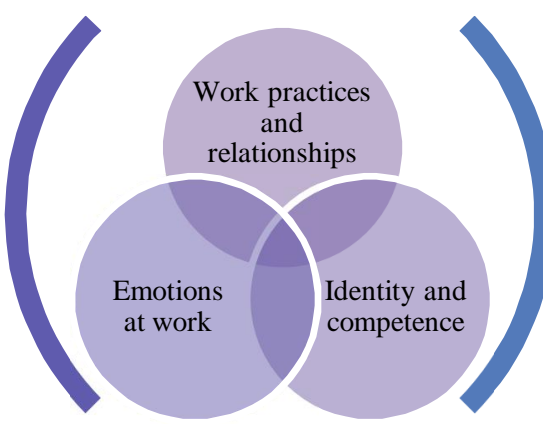

Work-related learning in different areas

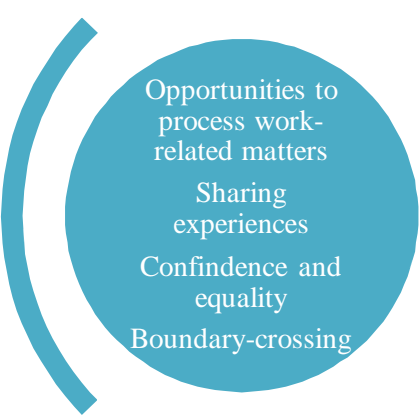

Supportive social conditions

Figure 1. Learning framed by professional agency through the social conditions of training settings.

As Figure 1 highlights, diverse work-related learning occurred in the three complementary training settings. For example, in identity coaching and leadership coaching programmes, the participants crafted their professional identities and gained a novel understanding and skills relating to emotions and their utilisation at work. The participants in the identity coaching programme and work conference also reported that they had learnt to become more active in their professional relationships. In these settings, a strengthened collective identity and transformations in shared work practices also occurred.

In line with other scholars (Billett 2011; Harteis and Goller 2014; Smith 2012), this paper has illustrated that professional agency and learning - notably understood as the crafting of professional identities and work practices - are closely intertwined. Professional agency is understood here as being enacted by making decisions, choices, and suggestions and by influencing professional identities, work practices, and relationships. During the training settings, different forms of professional agency emerged (Figure 1). One could say that transformative agency notably enhanced work- 
related learning. First, transformative agency emerged in the identity and leadership coaching programmes and resulted in changes in professional identities at the individual and collective levels. Further, making suggestions for developing shared work practices and/or making a difference in individual work practices emerged in the identity coaching programme and work conference. Dialogical and proactive forms of agency via expressing and presenting one's own ideas and expanding others' suggestions were also manifested as part of the development of shared work practices in the work conference. Professional agency can vary from developmental and transformationoriented actions to resistant activities (e.g. Toom et al. 2015); the latter was also the case in the work conference in relation to power relations. Further, resisting agency was found to hinder the development of shared work practices.

The empirical findings also suggest that social conditions - which can be understood as promoting the emergence of professional agency and work-related learning - include enabled boundary-crossing between various professions and viewpoints, a confidential and equal atmosphere, and the sharing of experiences. In agency-promoting learning events, therefore, it is essential to recognise and reduce constraints on professional agency (e.g. unequal power relations) and create an open and confidential atmosphere for experimentation, innovation, and sharing experiences to support work-related learning. Therefore, in emphasising an agentic approach to learning, the role of social contexts, practices, and relationships for professional agency and learning should not be ignored (see also Billett 2010; Evers, Kreijns, and van der Heijden 2016; Reich et al. 2015; Riveros et al. 2012).

The contribution of this paper lies in its agentic perspective on work-related learning and ways of fostering it. Agentic perspective implies that individuals and collectives should be seen as active crafters of their professional identities and work 
practices. Professional agency enacted by professionals is a necessary condition for work-related learning. Previous discussions mostly focused on agency as a means of transforming work practices and activities; consequently, they concentrated on supporting these kind of actions (e.g. Engeström 2011). This paper suggests that more attention should be paid to the agency of professionals for their learning (see also Lovett et al. 2015), especially in terms of professional identity. Amid a changing working life, the crafting of professional identities becomes an important aspect of learning, as it further contributes to the approach to work, collaborations, and the improvement of work practices. As Philpott and Oates (2016) argue, it may not be possible to change social practices without cultivating identities. Overall, we suggest that work-related learning should be understood as being grounded in the forms of professional agency and as being supported by social conditions (see also Billett 2011; Smith 2012).

In this paper, we presented empirical evidence from three work-related training settings. However, future research is needed to determine the premises, processes, and long-term outcomes of comprehensive learning interventions designed to support professional agency. It is also important to investigate what the most effective practices and methods are for supporting professional agency in, and for, work-related learning. The learning processes within the addressed work-related training settings shared a connection to emotions. The emphasis in future investigations should be on how emotions are embedded in learning (as the antecedents and consequences of the learning process).

In the future, the main challenges will be to develop frameworks and structures to support professional learning, which is collective, dynamic, and embedded in everyday practices, yet speak to the very real concerns of professionals, organisations, and professional bodies (Reich et al. 2015). Although the training settings presented 
here would be seen as worthwhile for supporting professional agency and learning, we agree with these authors that learning and practice should be understood as being emergent and relational (see also Billett 2010), and that there is a need to root the agentic perspective in fostering learning in the everyday work of professionals.

To do this, we must particularly spotlight the leaders and the cultivation of leadership practices (see also Hökkä and Vähäsantanen 2014). This implies that the leaders should be able to support employees' professional agency in taking responsibility and acting in order to influence their individual work, reshape professional identities, and make real changes relative to shared work practices. For leaders, this also means a responsibility to create events and interactions in their everyday work so that professionals can work together with individual and shared workrelated matters by analysing, sharing, and utilising their resources (e.g. experiences), and become strengthened to make meaningful decisions concerning work-related matters, such as professional identities and practices. We emphasise a particular need to create arenas to enhance this kind of collective agency to renew work, work communities, and organisations. This shared crafting of work might be more successful than an individual approach because it might be easier to face the developmental challenges of work communities and organisations together than alone.

\section{Acknowledgements}

This work was supported by the Academy of Finland [Grant number 288925, The Role of Emotions in Agentic Learning at Work] and the Finnish Work Environment Fund [Grant number 112125]. 


\section{References}

Admiraal, W., W. Lockhorst, and J. van der Pol. 2012. "An Expert Study of a Descriptive Model of Teacher Communities.” Learning environments research 15 (3): 345-361.

Alasoini, T. 2011. "Workplace Development as Part of Broad-based Innovation Policy: Exploiting and Exploring Three Types of Knowledge.” Nordic Journal of Working Life Studies 1 (1): 23-43.

Beijaard, D., P. Meijer, and N. Verloop. 2004. "Reconsidering Research on Teachers' Professional identity." Teaching and Teacher Education 20 (2): 107-128.

Billett, S. 2010. "Lifelong Learning and Self: Work, Subjectivity and Learning." Studies in Continuing Education 32 (1): 1-16.

Billett, S. 2011. "Subjectivity, Self and Personal Agency in Learning through and for work." In The SAGE Handbook of Workplace Learning, edited by Malloch, M., L. Cairns, L. Evans, and B. O’Connor, 60-72. Sage: London.

Carroll, B., and L. Levy. 2010. "Leadership Development as Identity Construction." Management Communication Quarterly 24 (2): 211-231.

Collin, K., S. Paloniemi, and K. Vähäsantanen. 2015. "Multiple Forms of Professional Agency for (Non)Crafting of Work Practices in Hospital Organisation.”. Nordic Journal of Working Life Studies 5: (3), 63-83.

Davey, R. 2013. The Professional Identity of Teacher Educators: Career on the Cusp? Routledge: London.

Day, D., and M. Harrison. 2007. "A Multilevel, Identity-based Approach to Leadership Development." Human Resource Management Review 17 (4): 360-373.

Emirbayer, M., and A. Mische. 1998. "What is Agency?" American Journal of Sociology 103 (4): 962-1023.

Engeström, Y. 2011. "From Design Experiments to Formative Interventions." Theory \& Psychology 21 (5): 598-628.

Eteläpelto, A., K. Vähäsantanen, P. Hökkä, and S. Paloniemi. 2013. "What is Agency? Conceptualizing Professional Agency at Work." Educational Research Review (10): 45-65.

Eteläpelto, A., K. Vähäsantanen, P. Hökkä, and S. Paloniemi. 2014. "Identity and Agency in Professional Learning." In International Handbook of Research in 
Professional and Practice-Based Learning, edited by S. Billett, C. Harteis and H. Gruber, 645-672. Dordrecht: Springer.

Evers, A.T., K. Kreijns, and B. Van der Heijden. 2016. "The Design and Validation of an Instrument to Measure Teachers' Professional Development at Work." Studies in Continuing Education 38 (2): 162-178.

Geijsel, F., F. and Meijers, 2005. "Identity Learning: The Core Process of Educational Change." Educational Studies 31 (4): 419-430.

Gustavsen, B., and P. Engelstad. 1986. "The Design of Conferences and the Evolving Role of Democratic Dialogue in Changing Working Life.” Human Relations 39 (2): 101-115.

Haapasaari, A. and H. Kerosuo. 2015. "Transformative Agency: The Challenges of Sustainability in a Long Chain of Double Stimulation.” Learning, Culture and Social Interaction 4: 37-47.

Harteis, C. and M. Goller. 2014. "New Skills for New Jobs: Work Agency as a Necessary Condition for Successful Lifelong learning." In Promoting, Assessing, Recognizing and Certifying Lifelong Learning: International Perspectives and Practices, edited by Billett, S., T. Halttunen, and M. Koivisto, 37-56. Springer: Dordrecht.

van der Heijden, H., J. Geldens, D. Beijaard, and H. Popeijus. 2015. "Characteristics of Teachers as Change Agents." Teachers and Teaching: Theory and Practice 21 (6): 681-699.

Hökkä, P., and A. Eteläpelto. 2014. "Seeking New Perspectives on the Development of Teacher Education - A Study of the Finnish Context." Journal of Teacher Education 65: (1), 39-52.

Hökkä, P., and K. Vähäsantanen. 2014. "Agency-Centred Coupling - A Better Way to Manage an Educational Organization?" International Journal of Leadership in Education 17: (2), 131-153.

Hökkä, P., Vähäsantanen, K., and Mahlakaarto, S. 2017. 'Teacher educators' collective professional agency and identity: Transforming marginality to strength." Teaching and Teacher Education 63, 36-46.

Hökkä, P., K. Vähäsantanen, S. Paloniemi, S. Herranen, and A. Eteläpelto. (forthcoming). “Emotions and Agency in Leaders' Work: Towards Emotional Agency." 
Imants, J., T. Wubbels, and J. Vermunt. 2013. “Teachers' Enactment of Workplace Conditions and Their Beliefs and Attitudes toward Reform." Vocations and Learning 6 (3): 323-346.

Kalliola, S. and R. Nakari. 2007. "Renewing Occupational Cultures - Bridging Boundaries in Learning Spaces." International Journal of Educational Research 46 (3-4), 190-203.

Kira, M. 2010. "Routine-generating and Regenerative Workplace Learning." Vocations and Learning 3 (1): 71-90.

Kira, M., and D. Balkin. 2014. "Interactions between Work and Identities: Thriving, Withering, or Redefining the Self?" Human Resource Management Review 24 (2): 131-143.

Kirpal, S., A. Brown, and M. Dif. 2007. "The Individualisation of Identification with Work in a European Perspective". In Identities at Work, edited by A. Brown, S. Kirpal, and F. Rauner, 285-313. Springer: Dordrecht.

Leitch, R. 2010. "Masks as Self-study. Challenging and Sustaining Teachers' Personal and Professional Personae in Early-mid Career Life Phases." Teachers and Teaching: Theory and Practice 16 (3): 329-352.

Lovett, S., N. Dempster, and B. Flückiger. 2015. "Personal Agency in Leadership Learning Using and Australian Heuristic." Professional Development in Education 41 (1): 127-143.

Lukic, D., A. Margaryan, and A. Littlejohn. 2013. "Individual Agency in Learning from Incidents." Human Resource Development International 16 (4): 409-425.

Mahlakaarto, S. 2014. “Työidentiteetit pelissä ja peilissä - Menetelmällisiä ratkaisuja toimijuuden vahvistamiseen [Work Identities at Stake and in the Mirrow Practical Tools for Supportig Agency]”. In Ammatillisen toimijuuden ja työssä oppimisen vahvistaminen - Luovia voimavaroja työhön! [Strengthening Professional Agency and Learning at Work - Creative Resources to Work!], edited by P. Hökkä, S. Paloniemi, K. Vähäsantanen, S. Herranen, M. Manninen, and A. Eteläpelto, 47-65. University of Jyväskylä; Jyväskylä.

McAlpine, L., and C. Amundsen. 2015. "Early Career Researcher Challenges: Substantive and Methods-based Insights." Studies in Continuing Education 37 (1): $1-17$. 
Molleman, E., and F. Rink. 2015. "The Antecedents and Consequences of a Strong Professional Identity among Medical Specialities." Social Theory \& Health 13 (2): 46-61.

Paloniemi, S., and K. Collin. 2012. "Discursive Power and Creativity in InterProfessional Work." Vocations and Learning 5: (1), 23-40.

Philpott, C. and C. Oates, 2016. “Teacher Agency and Professional Learning Communities: What can Learning Rounds in Scotland Teach Us?' Professional Development in Education. Published online: DOI:

$10.1080 / 19415257.2016 .1180316$

Priestley, M., G. Biesta, and S. Robinson. 2015. Teacher Agency: An Ecological Approach. London: Bloomsbury Academic.

Pyhältö, K., J. Pietarinen, and T. Soini. 2015. “Teachers' Professional Agency and Learning - From Adaption to Active Modification in the Teacher Community." Teaching and Teachers: Theory and Practice 21 (7): 811-830.

Reich, A., D. Rooney, and D. Boud. 2015. "Dilemmas in Continuing Professional Learning: Learning Inscribed in Frameworks or Elicited from Practice.” Studies in Continuing Education 34 (2): 131-141.

Riveros, A., P. Newton, and D. Burgess. 2012. “A Situated Account of Teacher agency and Learning: Critical Reflections on Professional Learning Communities." Canadian Journal of Education 35 (1): 202-216.

Ruohotie-Lyhty, M. and J. Moate. 2016. "Who and How? Preservice Teachers as Active Agents Developing Professional Identities." Teaching and Teacher Education 55 (4): $318-327$.

Sandelowski, M., and J. Barroso. 2006. Handbook for Synthesizing Qualitative Research. New York: Springer Publishing Company.

Smith, R. 2012. "Clarifying the Subject Centred Approach to Vocational Learning Theory: Negotiated Participation.” Studies in Continuing Education 34 (2): 159_ 174.

Taylor, S. and D. Ladkin. 2009. "Understanding Arts-based Methods in Managerial Development." Academy of Management Learning and Education 8 (1): 55-69.

Timulak, L. 2009. "Meta-analysis of Qualitative Studies: A Tool for Reviewing Qualitative Research Findings in Psychotherapy.” Psychoteraphy Research 19 (4-5): 591-600. 
Toom, A., K. Pyhältö, and F. Rust. 2015. “Teachers' Professional Agency in Contradictory Times." Teachers and Teaching: Theory and Practice 21 (6): $615-623$.

Townsend, T. and J. MacBeath, ed. 2011. International Handbook of Leadership for Learning. Springer: Dordrecht.

Tynjälä, P. 2013. "Toward a 3-P Model of Workplace Learning: A Literature Review." Vocations and Learning 6 (1): 11-36.

Virkkunen, J. 2006. "Dilemmas in Building Shared Transformative Agency." Activités 3 (1): $19-42$.

Vähäsantanen, K. 2015. "Professional Agency in the Stream of Change: Understanding Educational Change and Teachers' Professional Identities." Teaching and Teacher Education 47, 1-12.

Vähäsantanen, K., P. Hökkä, S. Paloniemi, S. Herranen, and A. Eteläpelto, 2016. "Professional learning and agency in an identity coaching programme." Professional Development in Education. Published online: http://dx.doi.org/10.1080/19415257.2016.1231131

Vähäsantanen, K., S. Paloniemi, P. Hökkä, and A. Eteläpelto. (forthcoming). “An Agency-promoting Learning Arena for Developing Shared Work Practices." In Agency at Work: An Agentic Perspective on Professional Learning and Development, edited by M. Goller and S. Paloniemi. Dordrecht: Springer. 